\title{
Scripta Medica, Volume 51, 2020: a Short Overview
}

\author{
Miloš P Stojiljković
}

(1) Editor-in-Chief, Scripta Medica.

\section{Abstract}

This editorial presents the analysis of volumes 50 (2019) and 51 (2020) of Scripta Medica. Original articles made $53 \%$ of 80 articles published in these two volumes. Article rejection rate was $38 \%$. Mean duration of period until reaching the first decision on an article was 20 days, while mean time until reaching the final decision was 31 days. Mean time needed for accepting the revised manuscript was 3 days, reflecting a significant decrease from 5 days in 2019 to 2 days in 2020. Mean time needed for reaching a decision to reject an article was 7 days. Coverage of the journal included both basic and clinical research and a considerable space was devoted to articles on COVID-19. Further efforts will be made in order to reach a more international recognition of the journal.

Key words: Scripta Medica; Biomedical journal; Editorial process; Research articles.

Correspondence:

MILOŠ P STOJILJKOVIĆ

E: milos.stojilikovic@med.unibl.org

\section{ARTICLE INFO}

Received: 28 December 2020 Accepted: 28 December 2020
On 6 August 2018 a new Editorial Office and Editorial and Advisory Boards of the scientific biomedical journal Scripta Medica were formed. ${ }^{1}$ Since 2019, the journal started to appear quarterly (in March, June, September and December). During these two years, a new layout of the journal was introduced and Scripta Medica gained the Directory of Open Access Journals (DOAJ) coverage. End of this tumultuous year is a good Table 1: Structure of volumes 50 (2019) and 51 (2020) of Scripta Medica

\begin{tabular}{l|rr|r|r|rr}
\hline Type of article & \multicolumn{2}{c}{2019} & \multicolumn{2}{c}{$\mathbf{2 0 2 0}$} & \multicolumn{2}{c}{ Total } \\
& Number & \% & Number & \% & Number & \% \\
\hline Editorial & 4 & 12.5 & 4 & 8.33 & 8 & 10.00 \\
\hline Letters to the Editor & 0 & 0.00 & 1 & 2.08 & 1 & 1.25 \\
\hline Original & 15 & 46.88 & 27 & 56.25 & 42 & 52.50 \\
\hline Review & 1 & 3.13 & 3 & 6.25 & 4 & 5.00 \\
\hline Current topic & 2 & 6.25 & 2 & 4.17 & 4 & 5.00 \\
\hline Special & 2 & 6.25 & 1 & 2.08 & 3 & 3.75 \\
\hline History of medicine & 1 & 3.13 & 3 & 6.25 & 4 & 5.00 \\
\hline Professional & 2 & 6.25 & 2 & 4.17 & 4 & 5.00 \\
\hline Case report & 5 & 15.63 & 4 & 8.33 & 9 & 11.25 \\
\hline Obituary & 0 & 0.00 & 1 & 2.08 & 1 & 1.25 \\
\hline Total & 32 & 100.00 & 48 & 100.00 & 80 & 100.00 \\
\hline
\end{tabular}

occasion to look back at the accomplishments of Scripta Medica, in order to ascertain its strong points but also the areas where some improvement would be necessary.

Volume 51 (2020) contained 48 articles, $50 \%$ more than the volume 50 (Table 1).

It can be noticed that this increase was accompanied by the increase in percentage of original articles and the decrease in the percentage of case reports.

A total of 140 manuscripts was received during the last two years and their status is given in Table 2.

The rejection rate was $35 \%$ in 2019 and it was increased to $41 \%$ in 2020 , resulting in the overall rejection rate of $38 \%$.

Efficacy of critical phases of processing of the received manuscripts is presented in Table 3. For those manuscripts that were eventually 
Table 2: Status of manuscripts, Scripta Medica

\begin{tabular}{|c|c|c|c|c|c|c|}
\hline Decision status & $\begin{array}{r}20 \\
\text { Number }\end{array}$ & $\begin{array}{l}19 \\
\% \text { of } \\
\text { decided }\end{array}$ & $\begin{array}{r}20 \\
\text { Number }\end{array}$ & $\begin{array}{l}20 \\
\% \text { of } \\
\text { decided }\end{array}$ & $\begin{array}{r}\text { To } \\
\text { Number }\end{array}$ & $\begin{array}{l}\text { tal } \\
\% \text { of } \\
\text { decided }\end{array}$ \\
\hline Received & 53 & & 87 & & 140 & \\
\hline Decided & 49 & 100.00 & 85 & 100.00 & 134 & 100.00 \\
\hline Rejected & 17 & 34.69 & 34 & 40.00 & 51 & 38.06 \\
\hline Accepted & 32 & 65.31 & 51 & 60.00 & 83 & 61.94 \\
\hline a) in current year & 30 & 61.22 & 48 & 56.47 & 78 & 58.21 \\
\hline b) not in current year & 2 & 4.08 & 3 & 3.53 & 5 & 3.73 \\
\hline Pending review & 4 & & 6 & & 6 & \\
\hline
\end{tabular}

Table 3: Duration of decision-making process, Scripta Medica

\begin{tabular}{|c|c|c|c|c|c|c|}
\hline \multirow[b]{2}{*}{ Editorial milestone } & \multicolumn{2}{|l|}{2019} & \multicolumn{2}{|l|}{2020} & \multicolumn{2}{|c|}{ Total } \\
\hline & Mean \pm SD & Range & Mean \pm SD & Range & Mean \pm SD & Range \\
\hline First decision (days) & $16.73 \pm 13.42$ & $1-58$ & $21.75 \pm 35.62$ & $1-211$ & $19.73 \pm 28.34$ & $1-211$ \\
\hline Accepted (days) & $31.00 \pm 23.69$ & $2-126$ & $26.98 \pm 39.13$ & $1-214$ & $30.76 \pm 38.87$ & $1-216$ \\
\hline Revision-acception (days) & $5.39 \pm 4.88$ & $1-18$ & $1.60 \pm 1.38$ & $1-9$ & $3.11 \pm 3.72$ & $1-18$ \\
\hline Rejection (days) & $5.50 \pm 8.03$ & $1-20$ & $5.59 \pm 8.27$ & $1-31$ & $6.87 \pm 11.55$ & $1-61$ \\
\hline
\end{tabular}

accepted, mean time period until the first editorial decision was made was 20 days, while the mean final acceptance time was 31 days. This relatively long time was a consequence of the lengthy reviewing process. It can be seen that the mean acceptance time after receiving peer-reviews was only 3 days, reflecting a sharp decrease from 5 days in 2019 to only 2 in 2020, while mean time for reaching a decision to reject the submission was 7 days.

Regarding the content of the volume 51, an effort was made to present results of both basic and clinical research. At the same time, a considerable space was dedicated to the coverage of COVID-19 pandemic. ${ }^{2-10}$ It is an intention of the Editorial Board to continue to diversify the content of Scripta Medica and improve the editorial process in order to make it more attractive for international audience.

\section{Acknowledgements}

The author wishes his gratitude to Dr Žana M Maksimović for her help in providing the statistical analysis of the Scripta Medica editorial database.

\section{Conflict of interest}

None.

\section{References}

1. Stojiljković MP. On the occasion of the fiftieth volume of the Scripta Medica (Banja Luka). Scr Med 2019;50(4):145-7.

2. Mijović B. COVID-19 - Lessons Learned. Scr Med 2020;51(1):1-5.

3. Igić R. Pharmacologist's view of the new Corona virus. Scr Med 2020;51(1):6-8.

4. Stojiljković MP. COVID-19 Pandemic, passing of Professor Folke Sjöqvist and other topics. Scr Med 2020;51(2):67-8.

5. Bhandari S, Sharma R, Singh Shaktawat A, Banerjee S, Patel B, Tak A, et al. COVID-19 related mortality profile at a tertiary care centre: a descriptive study. Scr Med 2020;51(2):69-73.

6. Aćimović J, Jandrić Lj, Đaković Dević J, Bojanić J, Subotić B, Radojčić T, et al. Epidemiological characteristics of COVID-19 infection in the Republic of Srpska: a hundred days survey. Scr Med 2020;51(2):74-80.

7. Janković S. Current status and future perspective of coronavirus disease 2019: a review. Scr Med 2020;51(2):101-9.

8. Stajić M, Maksimović ŽM, Verhaz A. COVID-19 pneumonia: when negative PCR testing does not rule out the disease. Scr Med 2020;51(2):120-3.

9. Janković SM. Antiviral therapy of COVID-19. Scr Med 2020;51(3):131-3.

10. Bhandari S, Shaktawat AS, Tak A, Shukla J, Gupta J, Patel B, et al. Relationship between ABO blood group phenotypes and nCOVID-19 susceptibility - a retrospective observational study. Scr Med 2020;51(4):21722. 